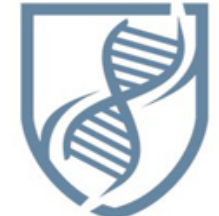

Journal of Bioscience and Applied Research

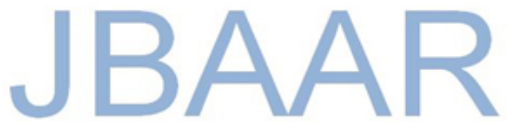

WWW.JBAAR.ORG

\title{
Potentiation of antifibrotic activity of Atacand using grape seed extract (Gervital) in male albino rats
}

\author{
Faten R. Abdel- Ghaffar ${ }^{1}$, Ibrahim A. El- Elaimy ${ }^{1}$, Azza M. Mohamed ${ }^{2}$ and Mona EL. Ghreeb ${ }^{1}$ \\ 1. Department of Zoology, Faculty of Science,Menoufia University, Shebin El- Kom, Egypt. \\ 2. Department of Therapeutic Chemistry, National Research Center, Dokki. Egypt. \\ Corresponding author e.mail:AbdelGhaffar_fr@yahoo.com)
}

\begin{abstract}
Carbon tetrachloride $\left(\mathrm{CCl}_{4}\right)$ is a known potent hepatotoxic agent. The present investigation clarified the ameliorative effects of Atacand and Gervital on $\mathrm{CCl}_{4}$-induced hepatotoxicity. 24 male albino rats were divided into 4 groups, 6 rats each. Group I, served as normal control. Group II, animals were injected subcutaneously with $\mathrm{CCl}_{4}$ $(1 \mathrm{ml} / \mathrm{kg}$ b.w.) twice a week for 90 days. Group III, rats were injected with $\mathrm{CCl}_{4}$, as Group II, then treated orally with Atacand ( $8 \mathrm{mg} / \mathrm{kg}$ b.w.), daily, for 30 days. Group IV, rats were injected with the same dose of $\mathrm{CCl}_{4}$ for 90 days, then treated with Atacand $(8 \mathrm{mg} / \mathrm{kg}$ b.w.) along with Gervital (100mg/kg b.w.), orally, daily for 30 days. $\mathrm{CCl}_{4}$ treatment showed a marked deterioration of liver function as a high increase in the levels of serum AST and ALT (153.8\% and $157.8 \%$, respectively). Also a significant decrease in liver antioxidant machinery was represented by reduced glutathione (GSH, 68.1\%), glutathione-stransferase (GST, 69.9\%) and glutathione reductase (GR, $65.65 \%$ ). On the other side, the levels of liver protein carbonyl groups (PCO) and lipid peroxidation (LPO) were elevated $439.6 \%$ and $258.7 \%$, respectively, compared to their control groups. These results indicated the oxidative damage as a result of $\mathrm{CCl}_{4}$-induced liver fibrosis. Both treatments with Atacand or Atacand + Gervital showed significant ameliorative effect for both liver and serum $\mathrm{CCl}_{4}$-induced alterations. The current study recorded that the treatment with Gervital along with Atacand scored more antifibrotic effectiveness than that of Atacand alone. So, Gervital acted as a potentiator for antifibrotic activity of Atacand.
\end{abstract}

Keywords: Atacand; Carbon tetrachloride; Gervital; Liver function; Oxidative stress.

\section{Introduction}

Hepatitis $\mathrm{C}$ virus is considered the most common etiology of chronic liver disease in Egypt - $20 \%$ of those progress to cirrhosis, and possibly $2-3 \%$ per year die as a result of its complications or hepato-cellular carcinoma.

Liver is the main detoxifying organ in the body, and as such it possesses a high metabolic rate and it is subjected to many insults potentially causative of oxidative stress. Consequently, a correct status of the hepatic antioxidant defense system is of major importance for the maintenance of health (Ahmed and Fatani, 2007).

Hepatic fibrosis is a reversible wound-healing response to liver injury, which has the potential to progress to cirrhosis. Several studies have shown that hepatic fibrosis is a reversible disease; therefore an effective treatment would probably prevent or reverse the fibrotic process in the liver (Farci et al., 2004; Satapathy et al., 2007). $\mathrm{CCl}_{4}$ intoxication, give a suitable animal model, similar to the human fibrosis. Carbon tetrachloride $\left(\mathrm{CCl}_{4}\right)$ is one of the chlorinated hydrocarbons that have a widespread use in various industries as a solvent. On the other hand, exposure to $\mathrm{CCl}_{4}$ takes place by inhalation, ingestion or absorption through the skin.

Potent hepatotoxin in a variety of experimental animal models (Weber et al., 2003), and induces necrosis (Sivikova et al., 2001) and apoptosis in the liver. Prolonged administration of $\mathrm{CCl}_{4}$ leads to fibrosis, cirrhosis and hepatic carcinoma (Wernke and Schnell, 2004).

Atacand (Candesartan cilexetil) is a selective angiotensin II 
(AT-II) type 1 receptor (AT1-R) blocker widely used as an antihypertensive in clinical practice and safe when
administered for a long time (Weinberg et al., 2004; Rosei et al., 2005). Paizis et al. (2002) reported that Angiotensin II (AT-II) is the principal effector molecule of the renin angiotensin system (RAS). It is synthesized in chronically damaged tissues by resident myofibroblasts (Katwa et al., 1997). Locally produced AT-II binds to angiotensin type 1 (AT1) receptors to stimulate angiogenesis, recruitment of inflammatory cells, growth of myofibroblasts and synthesis of extracellular matrix proteins. Due to its biological properties, the RAS is a target to prevent fibrosis in chronic inflammatory (Ruiz-Ortega et al., 2003). The blockade of the RAS, either with angiotensin- converting enzyme (ACE) inhibitors or AT1 antagonists, attenuates fibrosis development in experimental cardiac and renal fibrosis and are widely used as antifibrotic therapy in patients with chronic cardiac and renal diseases (Lijnen and Petrov, 2003).

Grapes and grape products are good sources of dietary flavonoids, which are powerful antioxidant compounds. Furthermore, the inedible contain some compounds that are able to scavenge superoxide radicals in living cells (Yilmaz and Toledo, 2004). Gervital which is grape seed extract contains proanthocyanidins as naturally occurring plant metabolites widely available in fruits, vegetables, nuts, flowers, wine, bilberry, ginko, black and green tea (Delnunay et al., 2002). A variety of proanthocyanidins have been shown to be anti-bacteria, anti-viral, anticarcinogenic (Carnésecchi et al., 2002), antiinflammatory (Li et al., 2000), anti-allergic and consequently reduce the concentration of reactive oxygen species (Bagchi et al., 1997) and low density lipoprotein oxidation (Rein et al., 2000).

The present study was designed to evaluate the effect of the co-treatment with Atacand (Atac), as an antifibrotic drug, and Gervital (Gerv), as a grape seed natural extract rich with proanthocyanidin, against $\mathrm{CCl}_{4}$ - induced liver fibrosis.

\section{Materials and Methods}

\section{Chemicals:}

Carbontetrachloride was obtained from Sigma-Aldrich company (St. Louis, MO, USA). Atacand (Candesartan Cilexetil) was obtained from Astrazenca for Pharmaceutical, Cairo, Egypt. Gervital (Proanthocyanidins) was obtained from Minapharm for pharmaceuticals, Cairo, Egypt. Thiobarbituric acid was obtained from Fluka (Berlin, Germany). The fine chemicals; Sodium nitrite, ammonium molybidate, 1chloro-2,4-dinitrobenzene(CDNB), ascorbic acid, ammonium acetate, riboflavin, Nitroblue Tetrazolium (NBT), sulfanilamide and trichloroacetic acid were obtained from Sigma-Aldrich (St. Louis, MO, USA).
Thiobarbituric acid was obtained from Fluka (Berlin, Germany).

\section{Animals:}

Male albino rats weighing 100-120 g were obtained from National Research Institute, Cairo, Egypt and acclimatized for two weeks prior to the experiment. They were maintained under standard laboratory conditions of room temperature $\left(22-25^{\circ} \mathrm{C}\right)$ and a relative humidity $(55 \pm 5 \%)$ with a light period of $12 \mathrm{~h} \mathrm{light/dark} \mathrm{cycle/day.} \mathrm{Animals}$ received standard laboratory balanced commercial diet and water ad libitum.

\section{Expirmental design:}

Twenty four rats were separated randomly into 4 groups, 6 rats each.

Group I: served as normal control, animals received saline solution.

Group II: animals were injected subcutaneously with $\mathrm{CCl}_{4}$ $(1 \mathrm{ml} / \mathrm{kg}$ b.w.) twice a week for 90 days (El-Elaimy and Abdel-Ghaffar, 1997).

Group III: rats were injected with the same dose of $\mathrm{CCl}_{4}$ for 90 days, then treated, orally, with Atacand $(8 \mathrm{mg} / \mathrm{kg}$ b.w.), daily, for 30 days (Yoshiji et al., 2001).

Group IV: rats were injected with the same dose of $\mathrm{CCl}_{4}$ for 90 days, then treated with Atacand ( $8 \mathrm{mg} / \mathrm{kg} \mathrm{b.w.)} \mathrm{along}$ with Gervital (100mg/kg b.w) (Bagchi et al., 2001), orally and daily, for 30 days

After 24 hours from the last treatment, the animals of each group were sacrificed by cervical dislocation then blood samples from hepato-portal vein were withdrawn. Serum was separated by centrifugation at $4000 \mathrm{rpm}$ for $15 \mathrm{~min}$, at $4{ }^{\circ} \mathrm{C}$. Liver was discarded, blotted dry, weighed and homogenized in cold, $0.15 \mathrm{M}, \mathrm{KCl}$ to give a final concentration of $10 \%(\mathrm{w} / \mathrm{v})$ homogenate. All samples were stored at $-20^{\circ} \mathrm{C}$ till biochemical analyses.

\section{Biochemical analysis:}

The Biochemical analyses were determined according to the corresponding methods. Serum AST and ALT activities (Reitman and Frankel, 1957). Liver reduced glutathione (GSH) content (Beutler and Kelley, 1963) and activities of liver antioxidant enzymes; glutathione- S- transferase (GST) (Habig et al., 1974), glutathione reductase (GR) (Carlberg and Mannervik, 1975). Also, liver lipid peroxidation (LPO) (Ruiz- Larrea et al., 1994) and protein carbonyl (PCO) (Levine et al., 1990) contents were assayed.

\section{Statistical analysis:}

Results are expressed as mean \pm S.E. Data were analyzed by SPSS software, version 19 (Chicago, IL, USA) followed 
by Student's t- test. $\mathrm{P}$ value $<0.05$ was considered statistically significant.

\section{Results}

$\mathrm{CCl}_{4}$ caused highly significant $(\mathrm{P}<0.001)$ elevation in activities of serum AST (153.8\%) and ALT (157.8\%) compared to control group. Atac-treatment ameliorated serum AST and ALT activities (31.95\% and 32.24\%), respectively. It reduced, significantly, the alterative $\mathrm{CCl}_{4-}$ induced effect, compared to $\mathrm{CCl}_{4}$ treated groups. On the other side Gerv + Atac co-treatment produced additive amelioration, for serum AST and ALT activities $(9.86 \%$ and $3.90 \%$ ), respectively, compared to $\mathrm{CCl}_{4}+$ Atac treated groups (Table 1).

On the other hand, $\mathrm{CCl}_{4}$ caused a highly significant $(\mathrm{P}<$ $0.001)$ depletion $\quad(68.1 \%)$ in the level of liver GSH. Also, liver antioxidant enzymes GST and GR activities decreased with $\mathrm{CCl}_{4}$ treatment $(69.9 \%$ and65.65\%), respectively, compared to their control values. Treatment with Atac significantly restored the level of liver GSH (70.33\%) and liver antioxidant enzymes activities of GST and GR (109.19\% and66.66\%), respectively. But these levels still, significantly, lesser than their normal levels. Atac+Gerv cotreatment significantly resulted in more regulation for GSH level (11.94\%) and liver antioxidant enzymes GST and GR activities $(13.73 \%$ and $16.66 \%)$ respectively, compared with $\mathrm{CCl}_{4}+$ Atac treatment groups (Table 2).

$\mathrm{CCl}_{4}$-intoxication significantly increased the levels of LPO and PCO (258.7\% and 439.6\%), respectively, when compared to their control groups. However, LPO and PCO levels have been restored with Atac-treatment (55.87\% and $32.23 \%$ ), respectively, compared with $\mathrm{CCl}_{4}$ treated groups. On the other side, Atac + Gerv co-treatment showed more restoration for hepatic LPO and PCO levels (3.96\% and13.18\%), respectively, compared with $\mathrm{CCl}_{4}+\mathrm{Atac}$ treatment groups (Figs. 1\& 2).
Table 1. Serum AST \& ALT activities in different studied animal groups.

\begin{tabular}{|l|l|l|}
\hline Expirmental groups & \multicolumn{1}{|c|}{$\begin{array}{c}\text { AST } \\
(\mathrm{U} / \mathrm{L})\end{array}$} & \multicolumn{1}{c|}{$\begin{array}{c}\text { ALT } \\
(\mathrm{U} / \mathrm{L})\end{array}$} \\
\hline Control & $97.40 \pm 1.12$ & $61.60 \pm 1.03$ \\
\hline $\mathbf{C C l}_{\mathbf{4}}$ & $247.20 \pm 1.39^{\mathrm{a}^{* *}}$ & $158.80 \pm 1.74^{\mathrm{a}^{* *}}$ \\
& $\mathbf{( 1 5 3 . 8 \% )}$ & $\mathbf{( 1 5 7 . 8 \% )}$ \\
\hline $\mathbf{C C l}_{\mathbf{4}}+$ Atac & $168.20 \pm 1.66^{\mathrm{b}^{* *}}$ & $107.60 \pm 1.21^{\mathrm{b}^{* *}}$ \\
& $\mathbf{( 3 1 . 9 5 \% )}$ & $\mathbf{( 3 2 . 2 4 \% )}$ \\
\hline $\mathbf{C C l}_{\mathbf{4}}+$ Atac + Gerv & $151.60 \pm 1.86^{\mathrm{c}^{* *}}$ & $103.40 \pm 1.21^{\mathrm{c}^{*}}$ \\
& $\mathbf{( 9 . 8 6 \% )}$ & $\mathbf{( 3 . 9 0 \% )}$ \\
& & \\
& & \\
\hline
\end{tabular}

Each value represents mean \pm S.E. $(\mathrm{n}=6)$. (\%) value is compared to the corresponding group. (a) significant compared to the control group, (b) significant compared to the $\mathrm{CCl}_{4}$ treated group and (c) significant compared to the to the $\mathrm{CCl}_{4}+\mathrm{Atac}$ treated group. (*) $\mathrm{P}<0.05$ and (**) $\mathrm{P}<0.001$.

Table 2. Liver GSH content, GST and GR activities in different studied animal groups.

\begin{tabular}{|c|c|c|c|}
\hline $\begin{array}{l}\text { Expiremental } \\
\text { groups }\end{array}$ & $\begin{array}{r}\text { (GSH) } \\
\text { (mg/gtissue) }\end{array}$ & $\begin{array}{l}\text { (GST) } \\
\text { (nmole CDNB } \\
\text { conjugate } \\
\text { formed } / \mathrm{min} / \mathrm{ml} \text { ) }\end{array}$ & $\begin{array}{l}\quad \text { (GR) } \\
\text { (nmole/NADP } \\
\mathrm{H} \\
\text { oxidized/min/ } \\
\mathrm{ml} \text { ) }\end{array}$ \\
\hline Control & $74.00 \pm 1.41$ & $57.80 \pm 1.16$ & $31.40 \pm 1.08$ \\
\hline $\mathrm{CCl}_{4}$ & $\begin{array}{c}23.60 \pm 1.21^{\mathrm{a}^{* *}} \\
(\mathbf{6 8 . 1} \%)\end{array}$ & $\begin{array}{c}17.40 \pm 0.81^{\mathrm{a}^{* *}} \\
(\mathbf{6 9 . 9 \%})\end{array}$ & $\begin{array}{c}10.80 \pm 1.16^{\mathrm{a}^{* 7}} \\
(\mathbf{6 5 . 6 \% )}\end{array}$ \\
\hline $\mathrm{CCl}_{4}+\mathrm{Atac}$ & $\begin{array}{c}40.20 \pm 1.36^{b^{5 *}} \\
(\mathbf{7 0 . 3 3 \% )}\end{array}$ & $\begin{array}{c}36.40 \pm 1.03^{b^{* *}} \\
(\mathbf{1 0 9 . 1 9 \% )}\end{array}$ & $\begin{array}{c}18.00 \pm 1.58 \\
\mathrm{~b}^{* *} \\
(\mathbf{6 6 . 6 6 \% )}\end{array}$ \\
\hline $\begin{array}{l}\mathrm{CCl}_{4}+\mathrm{Atac}+ \\
\text { Gerv }\end{array}$ & $\begin{array}{c}45.00 \pm 1.30^{\mathrm{c}^{*}} \\
(\mathbf{1 1 . 9 4 \% )}\end{array}$ & $\begin{array}{c}41.40 \pm 1.47^{\mathrm{c}^{*}} \\
(\mathbf{1 3 . 7 3 \% )}\end{array}$ & $\begin{array}{c}21.00 \pm 1.00^{\mathrm{c}} \\
(\mathbf{1 6 . 6 6 \% )}\end{array}$ \\
\hline
\end{tabular}

Each value represents mean \pm S.E. $(\mathrm{n}=6)$. (\%) value is compared to the corresponding group. (a) significant compared to the control group, (b) significant compared to the $\mathrm{CCl}_{4}$ treated group and (c) significant compared to the to the $\mathrm{CCl}_{4}+\mathrm{Atac}$ treated group. $\left(^{*}\right) \mathrm{P}<0.05$ and $(* *) \mathrm{P}<0.001$. 
Fig. 1. Liver LPO level in the different studied groups.

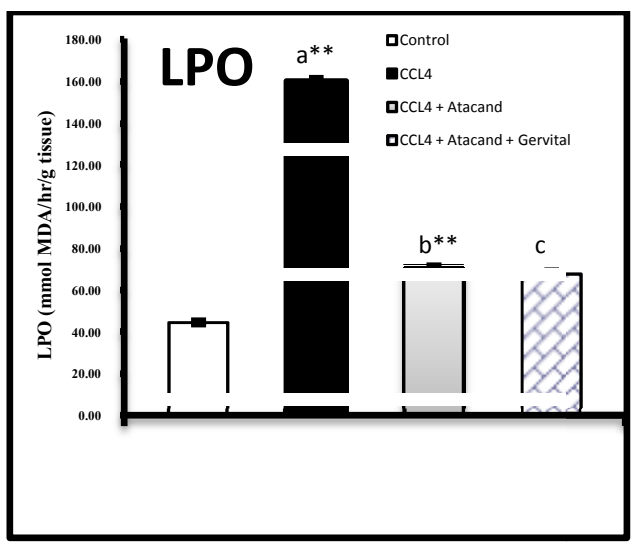

Each value represents mean \pm S.E. $(n=6)$. (a) significant compared to the control group, (b) significant compared to the $\mathrm{CCl}_{4}$ treated group and (c) significant compared to the $\mathrm{CCl}_{4}+$ Atac treated group. $\left({ }^{*}\right) \mathrm{P}<0.05$ and $(* *) \mathrm{P}<0.001$.

Fig. 2. Liver PCO level in the different studied groups.

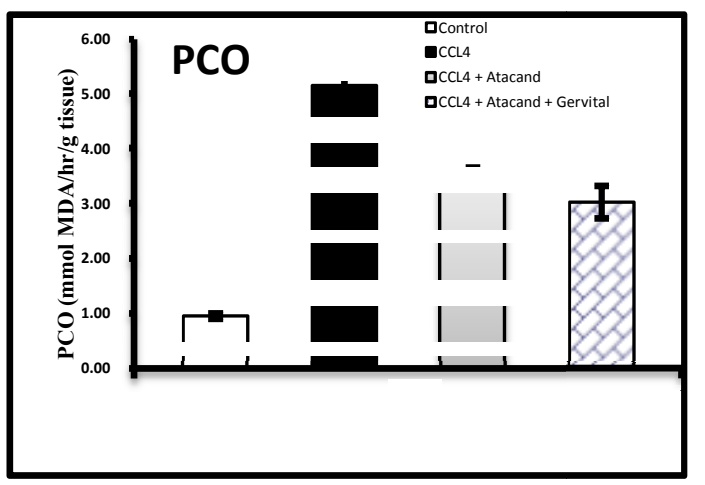

Each value represents mean \pm S.E. $(n=6)$. (a) significant compared to the control group, (b) significant compared to the $\mathrm{CCl}_{4}$ treated group and (c) significant compared to the $\mathrm{CCl}_{4}+$ Atac treated group. (*) $\mathrm{P}<0.05$ and $(* *) \mathrm{P}<0.001$.

\section{Discussion}

Oxidative stress is thought to play an important contributory role in the pathogenesis of numerous degenerative or chronic diseases (Ray and Husain, 2002). Human diseases, such as diabetes, neurodegenerative, cardiovascular diseases and specially carcinogenesis have been associated with oxidative stress. This condition occurs in the tissue when the concentration of the generated reactive oxygen species exceeds its antioxidant capability (Nakabeppu et al., 2006). AST and ALT are cytosolic enzymes of the hepatocytes. They are involved in the breakdown of amino acids into $\alpha$-keto acids (Maiti et al., 2004).

In our study, $\mathrm{CCl}_{4}$ provoked significant elevation in serum AST and ALT activities, reflecting impaired liver function. This result is in agreement with a previous study which reported that $\mathrm{CCl}_{4}$ toxicity developed significant hepatic damage as manifested by a significant increase in activities of AST and ALT, which are indicators of hepatocyte damage and loss of functional integrity (Nabeshima et al., 2006).

It is well documented that the toxicity of $\mathrm{CCl}_{4}$ is thought to involve two phases; first, $\mathrm{CCl}_{4}$ metabolization by cytochrome $\mathrm{P} 450$ in the hepatocytes produces the highly reactive $\mathrm{CCl}_{3}$ - radical, which leads to lipid peroxidation and membrane damage. The second step is a Kupffer cell mainly related inflammatory response. Kupffer cells are activated by free radicals and secrete cytokines that attract and activate neutrophils. Neutrophils themselves release reactive oxygen intermediates (ROIs), thereby enhancing the liver injury (Louis et al., 1998). So, any increase in AST and ALT activities reflects a leakage in plasma membrane permeability, which in turn, is associated with cell death. Moreover, they are best indicators of liver necrosis (Hemida and Mohafez, 2008).

Recently, Sirage et al. (2011) found that $\mathrm{CCl}_{4}-$ intoxication has a bad significant effect on the liver function, since the activities of serum AST and ALT were significantly higher than those of normal value.

All aerobic organisms have antioxidant defenses to remove or repair the damaged molecules. These antioxidants can protect the human body from free radicals and reactive oxygen species (ROS) effects. ROS related to the progress of many chronic diseases as well as lipid peroxidation (Lai et al., 2001; Gulcin et al., 2002).

The present study showed a highly significant reduction in GSH level after $\mathrm{CCl}_{4}$ administration. Several studies suggested that $\mathrm{CCl}_{4}$ administration cause depletion in GSH contents (Sirage, et al., 2011). On the same line Hayes et al. (2005) suggested that $\mathrm{CCl}_{4}$ treatment depletes the hepatic GSH contents.

In general, GSH is one of the most common biologic non enzymatic antioxidant. Its function includes removel of free radicals such as $\mathrm{H}_{2} \mathrm{O}_{2}$ and superoxide anions, maintenance of membrane protein thiols and acting as a substrate for GPx and GR (Naik and Panda, 2007). GSH deficiency contributes to oxidative stress, which plays a key role in liver disease, cystic fibrosis, sickle cell anemia, cancer, heart attack, stroke and diabetes (Rana et al., 2002). On the other side Hayes et al. (2005) revealed that GSH conjugates play a major role in eliminating the $\mathrm{CCl}_{4}$ induced toxic metabolites which are the main cause of liver 
injuries. So, the maintenance of sufficient glutathione level is important for the prevention of $\mathrm{CCl}_{4}$-induced damages.

Our data confirmed the concept that oxidative stress plays a role in $\mathrm{CCl}_{4}$-induced tissue damage, whereas GSH reduction was accompanied by reduction in the antioxidant enzyme defense system represented as depletion in the levels of GST and GR. This is in agreement with the recent studies demonstrated that $\mathrm{CCl}_{4}$ significantly lowered the levels of hepatic antioxidants coupled with high indices of lipid peroxidation (Jadeja et al., 2011; Desai et al., 2012).

Herein, a decrease in the activities of antioxidant enzymes can be explained either with their induction during the conversion of free radicals into inactive metabolites or secondary with the direct inhibitory effect of $\mathrm{CCl}_{4}$ on enzymes activities.

The toxicity of $\mathrm{CCl}_{4}$ and its reactive metabolites may result from covalent (primary) interactions with critical target molecules such as DNA, lipids, protein, or carbohydrates, or from the alteration of target molecules via secondary bond formation of lipid peroxidation (LPO), generation of reactive oxygen species and glutathione depletion (Boll et al., 2001; Das et al., 2004). Our results showed that $\mathrm{CCl}_{4}$ administration increased the level of LPO. Surendran et al. (2011) showed that $\mathrm{CCl}_{4}$ administration resulted in elevation in the level of LPO. It was reviewed also that $\mathrm{CCl}_{4}$ treatment produced an elevation in the level of malonaldhyde (MDA) in the hepatic tissues (Bayraktar et al., 2012).

The increase in LPO levels suggests enhanced peroxidation leading to tissue damage and failure of the antioxidant defense mechanism to prevent the formation of excessive free radicals (Cetin et al., 2011).

Protein carbonyl groups (PCO), aldehydes and ketones, are produced by protein side chains when they are oxidized by almost all types of ROS (Beal, 2002).

Our data showed that $\mathrm{CCl}_{4}$ administration increased $\mathrm{PCO}$ level in liver. Stadtman (2004) discussed that exposure of proteins to reactive oxygen species can alter the physical and chemical structure of the target protein causing consequent oxidation loading to oxidation of hydrophobic amino acyl residues to hydroxyl and hydroxyperoxy(P$\mathrm{OOH}$ ) derivatives, protein carbonylation (PCO), oxidation of total sulfhydryl groups (T- SH), and many others. Our results were in agreement with Chen et al. (2013) and Kamel et al. (2010) who found that $\mathrm{CCl}_{4}$ toxicity caused a significant increase in protein carbonyl compared to the control group. The current study clarified that treatment with Atacand (candesartan cilexetil) markedly attenuated AST and ALT activities aganist $\mathrm{CCl}_{4}$ toxicity. This is supported by the early study that serum levels of transaminases return to normal with the healing of hepatic parenchyma and regeneration of hepatocytes (Thabrew et al., 1987). In other study D'Amico et al. (2001) showed that serum levels of transaminases return to normal with the healing of hepatic parenchyma and regeneration of hepatocytes after candesartan cilexetil adminstration. On the same line Rajesh and Latha (2004) showed that administration of candesartan cilexetil to rats caused a decrease in the activity of the serum, hepatic enzymes which may be a consequence of plasma membrane regeneration as well as the repair of hepatic tissue damage caused by $\mathrm{CCl}_{4}$. Sirag et al. (2011) reported that Atacand minimize the injuries and protect the liver from further side effect of $\mathrm{CCl}_{4}$. This suggested that candesartan cilexetil may have direct effect on fibrosis rather than indirect effect mediated by hepatoprotection (Tuncer et al., 2003).

Our results showed that, Atacand treatment impeded and consequently improved GSH level. Its treatment limited GSH reduction and restored the activity of GST and GR. Our results were in agreement with Sirag et al. (2011) who showed that the hepatic GSH level and GST activity were restored by treatment with candesartan cilexetil after $\mathrm{CCl}_{4}$ toxicity. Darwish and Abdel-aziz, (2006) discussed that candesartan cilexetil have an efficient role in manipulating liver fibrosis by minimizing cytokine and extracellular matrix proteins production as well as affecting oxidative stress parameters.

In the present study, Atacand treatment significantly provides strong restoration against lipid peroxidation induced by $\mathrm{CCl}_{4}$. As well as, ameliorative against PCO. Sirag et al. (2011) found that candesartan cilexetil treatment significantly decreased the serum markers of hepatic injury and lipid peroxidation against $\mathrm{CCl}_{4}-$ induced liver injury in rat. The outhers suggested that this finding may prove that candesartan cilexetil has an important role in hepatocyte regeneration. Consequently, a remarkable depletion in the alterations of $\mathrm{CCl}_{4}$ - induced hepatotoxicity was produced. Our results showed that, treatment with Gervital markedly attenuated AST and ALT activities aganist $\mathrm{CCl}_{4}$ toxicity. These results were in agreement with the finding obtained by Ahmed and Fatani (2007) who showed that oral administration of grape seed proanthocyanidin (GSP) in rats, significantly protected the liver and attenuated activities of the estimated liver enzymes ALT and AST. In earlier study (Joshi et al., 2000) stated that GSP administration resulted in a significant decrease in acetaminophen-induced serum aminotransferases elevation, hepatic DNA damage, and mortality rate. This clarified that treatment with Gervital protected plasma membranes from the attacking of free radicals and prevented their damage.

Our results showed that, Gervital treatment improved GSH level and restored the activity of GST and GR. These results decoumented the role of proanthocyanidins in 
protecting cells against oxidative stress caused by $\mathrm{CCl}_{4} \mathbf{5}$ References through modulation of metabolic functions, enhancement of detoxification pathways, and/or prevention of the interaction of xenobiotics with biological molecules (Bagchi et al., 2000). These results coincide with that of Shan et al. (2010) who stated that Grape seed proanthocyanidin extract (GSPE) can improve the activity of antioxidant GSH and GST in liver. This indicates that the antioxidant function of GSPE maybe work by increasing the activity of body's antioxidant enzymes.

The co-treatment of Gervital showed more restoration of hepatic LPO and PCO levels against $\mathrm{CCl}_{4}$ induced oxidative stress. Early, investigators have demonstrated the efficacy of proanthocyanidin as an inhibitor of lipid peroxidation and as a powerful free radical scavenger in vitro as well as in vivo (Ray et al., 1999). Our results matched with Chis et al. (2009) who found that long-term administration of GSE offers enhanced antioxidant potential and protection of tissue lipid peroxidation and protein oxidation.

In general, grape seed proanthocyanidin extract (Gervital) can clear off free radicals, protect the over-oxidative damage caused by free radicals (Feng et al., 2005; Spranger et al., 2008), and prevent a range of diseases caused by free radicals, such as myocardial infarction, atherosclerosis, drug-induced liver and kidney injury; what's more, it has functions of anti-thrombotic, anti-tumor, anti-mutagenic, anti-radiation, and anti-fatigue (Qin et al., 2006; Engelbrecht et al., 2007).

Bagchi et al. (2000) concluded that GSPE act as a safe, novel, highly potent and bioavailable free radical scavenger and antioxidant possessing a broad spectrum of health benefits. GSPE functions at the genetic level and promotes therapeutic efficacy. Further mechanistic and clinical studies are in progress to unveil the mechanism of this novel natural antioxidant.

We concluded that Atacand and Gervital possessed modulatory mechanism against $\mathrm{CCl}_{4^{-}}$induced liver toxicity. Atacand (Candesartan cilexetil), an AT-II type 1 receptor (AT1-R) blocker, have hepatomodulative effects and effectively delayed the progression of hepatic fibrosis. Gervital (Proanthocyanidins from grape seed), having a very important function as antioxidant, by which it potentiated the antifibrotic activity of Atacand. Their cotreatment can clean off the free radicals, and reduce the membrane lipid peroxidation leading to hepatocyte regeneration.Our study showed that Gervital added more strength to the ameliorative effect of Atacand through their co-treatment against $\mathrm{CCl}_{4}$-induced hepatic fibrosis.

Ahmed, A.A., Fatani, A.J. (2007). Protective effect of grape seeds proanthocyanidins against naphthalene-induced hepatotoxicity in rats. J Saudi Pharmaceutical, 15(1):38- 47.

Bagchi, D., Bagchi, M. Stohs, S.J. Das, D.K. Ray, S.D. Kuszynski, C.A. Joshi, S.S. Pruess, H.G. (2000). proanthocyanidin extract: importance in human health and disease prevention. J Toxicol., 148(2-3): 187-197.

Bagchi, D., Garg, A. Krohn, R.L. Bagchi, M. Tran, M.X. Stohs, S.J. (1997). Oxygen free radical scavenging abilities of vitamins $\mathrm{C}$ and $\mathrm{E}$, and a grape seed proanthocyanidin extract in vitro. Res. Commun. Mol. Pathol. Pharmacol., 95(2): 179-189.

Bagchi, D., Ray, S. Patel, D. Nagchi, M. (2001). Protection against drug and chemical-induced multiorgan toxicity by novel IH 63 grape seed proanthocvanidin extract. Drugs Exp. Clin. Res., 27(1): 3-15.

Bayraktar, N., Devay, D.S. Taslipinar, M.Y. Ömeroglu, S. Gumuslu, S. Kavutcu, M. Canbolat, O. (2012). The effects of stobadine on purine metabolism in rats treated with carbon tetrachloride. Turk J Med. Sci., 42 (5): 894-900

Beal, M.F. (2002). Oxidatively modified proteins in aging and disease. Free Radic. Biol. Med., 32(9):797-803.

Beutler, E.D., Kelly BM, (1963). Improved method for the determination of blood glutathione. $\mathrm{J}$ Lab. Clin. Med. 61:882-888.

Boll, M., Weber, L.W.D.; Becker, E. Stampfl, A. (2001). Mechanism of carbon tetrachloride-induced hepatotoxicity. Hepatocellular damage by reactive carbon tetrachloride metabolites. Z. Naturforsch., 56c: 649-659.

Carlberg, I., Mannervik, B. (1975). Glutathione level in rat brain. J Biol. Chem., 250: 4480- 4575.

Carnésecchi, S., Schneider, Y. Lazarus, A.S. Coehlo, D. Gossé, F. Raul, F. (2002). Flavanols and procyanidins of cocoa and chocolate inhibit growth and polyamine biosynthesis of human colonic cancer cells. Cancer Lett., 175(2): 147-155.

Cetin, A., Kaynar, L. Eser, B. Karadag, C. Saraymen, B. Ozturk, A. (2011). Beneficial Effects of Propolis on Methotrexate-Induced Liver Injury in Rats. Acta. Oncologica Turcica., 44(1): 18-23.

Chen, X., Ying, X. Zhang, W. Chen, Y. Shi, C. Hou, Y. Zhang, Y. (2013). The hepatoprotective effect of fraxetin on carbon tetrachloride induced hepatic fibrosis by antioxidative activities in rats. Int. Immun. pharmacol., 17(3): 543-547. 
Chis, I.C., Ungureanu, M.I. Marton, A. Simedrea, R. Muresan, A. Postescu, I.D. Decea, N.( 2009). Antioxidant effects of a grape seed extract in a rat model of diabetes mellitus. Diabetes and Vascular Disease Res., 6(3): 200- 204.

D’Amico, G., Garcia, T.G. Cales, P. Escorsell, A. Nevens, F. Cestari, R. (2001). Diagnosis of Portal 713 hypertension: how and when. In: Portal hypertension III. Proceedings of III Baveno international consensus workshop on definition, methodology and therapeutic strategies. Blackwell Science, Oxford.

Darwish, I.E., Abdel- aziz, H.K. (2006). Role of atte Simvastatin, Tetrandrine and Candesartan in dane experimental induced liver fibrosis in rats. Bll. Alex. 148.

Fac. Med., 42(1): 1110-1134.

Das, R.K., Das, S. Bhattacharya, S. (2004). Pat Protective effect of diphenylmethyl selenocyanate eval against carbon tetrachloride induced hepatotoxicity in
vivo. J Environ. Path. Toxicol. Oncol., 23(4): 287- Hur 296.

Jadeja, R.N., Thounaojam, M.C. Ansarullah, J.S. Patel, M.D. Patel, D.K. (2011). Toxicological evaluation and hepatoprotective potential of Clerodendron glandulosum. Coleb leaf extract. J Hum. Exp. Toxicol., 30(1):63-70.

Joshi, S.S., Kuszynski, C.A. Bagchi, M. Bagchi,

Delnunay, I.C., Castopnino, C. Cheze, C. D. (2000). Chemoprotective effects of grape seed Vercautercn, I. (2002). Isolation of polyphennlic proanthocyanidin extract on Chang liver cells. J. compounds from Vitis vinilcra by centritupal partition Toxicol., 155(1-3): 83- 90.

chromatography. I. Chrornatogr., 964: 1123-1128.

Kamel, H.H., Abd-El-Rahman, A.H. Ahmed,

Desai, S.N., Patel, D.K. Devkar, R.V. Patel, P.V. W.M.S. Mohamed, A.H. (2010). Protective Effect of Ramachandran, A.V. (2012). Hepatoprotective some Antioxidants against Ccl4-Induced Toxicity in potential of polyphenol rich extract of Mur-raya Liver Cells from BRL3A Cell Line. Am. J Sci., 6(10): koenigii: an in vivo study. Food Chem. Toxicol., 992-1003.

50:310-314.

Katwa, L.C., Campbell, S.E. Tyagi, S.C. Lee, S.J.

El-Elaimy, I.A., Abdel-Ghaffar, F.R. Cicila, G.T. Weber, K.T. (1997). Cultured (1997).Ameliorative effect of thiola against two myofibroblasts generate angiotensin peptides de novo. different experimentally inducedliver fibrosis.liver J Mol. Cell Cardiol, 29:1375-1386.

hydroxyproline and hexosamine. J Union Arab Biol., 8(A): 225-251.

Engelbrecht, A.M., Mattheyse, M. Ellis, B. Loos, pro B. Thomas, M. Smith, R. Peters, S. Smith, C. Myburgh, K. (2007). Proanthocyanidin from grape seeds inactivates the PI3-kinase/PKB pathway and induces apoptosis in a colon cancer cell line. Cancer Lett. 258(1): 144-153.

Farci, P., Roskams, T. Chessa, L. Peddis, G. 186 Mazzoleni, A.P. Scioscia, R. Serra, G. Lai, M.E. Loy, M. Caruso, L. Desmet, V. Purcell, R.H. Balestrieri, A. An (2004). Long-term benefit of interferon alpha therapy pro of chronic hepatitis D: regression of advanced hepatic fibrosis. Gastroenterol., 126(7): 1740- 1749.

Feng, Y.Z., Liu, Y.M. Fratkins, J.D. LeBlan, i M.H. (2005). Grape seed extract suppresses lipid ext peroxidation and reduces hypoxic ischemic brain
injury in neonatal rats. Brain Res. Bull., 66(2): 120127.
Lai, L.S., Chou, S.T. Chao, W.W. (2001). Studies on the antioxidative activities of hsian-tsao (Mesona procumbens Hemsl) leaf gum. J Agri. and Food Chem., 49, 963-968.

Levine, L., Garland, D. Oliver, C.N. Amici, A. Climent, I. Lenz, A. Ahn, B.W. Shaltiel, S. Stadtman, E.R. (1990). Determination of carbonyl content in oxidatively modified proteins. Methods Enzymol., 186: 464-478.

Li, W.G., Zhang, X.Y. Wu, Y.J. Tian, X. (2000). Anti-inflammatory effect and mechanism of proanthocyanidins from grape seeds. J Acta. Pharmacol. Sin., 22: 1117-1120.

Lijnen, P.J., Petrov, V.V. (2003). Role of intracardiac renin-angiotensin- aldosterone system in extracellular matrix remodeling. liver fibrosis. World J Gastroenterol., 14(7): 1108-1111.

Louis, H., Van Laethem, J.L. Wu, W. Quertinmont, E. Degraef, C. Van den Berg, K. (1998). Interleukin-10 controls neutrophilic infiltration, hepatocyte proliferation, and liver fibrosis 
induced by carbon tetrachloride in mice. Hepatology,

Rosei, E.A., Rizzoni, D. Muiesan, M.L. Sleiman, 28:1607-15.

I. Salvetti, M. Monteduro, C. (2005). Centro

Maiti, R., Jana, D. Das, U.K. Ghosh, D. (2004). (Candesartan on Atherosclerotic Risk factors) study Antidiabetic effect of rats. aqueous extract of seed of investigators. J Hypertens, 23:435- 444.

Tamarindus indica in streptozotocin-induced diabetic J Ethnopharmacol., 92(1): 85-91.

Ruiz-Larrea, M.B., Leal, A.M. Liza, M. Lacort,

Nabeshima, Y., Tazuma, S. Kanno, K. Hyogo, H. estradiol and 2-hydroxyestradiol on iron-induced lipid Iwai, M. Horiuchi, M. (2006). Antifibrogenic function peroxidation of rat liver microsomes. Steroids, 59: of angiotensin II type 2 receptor in $\mathrm{CCl}_{4}$-induced liver 383- 388 .

fibrosis. Biochem. Biophy. Res., 346:658-664.

Ruiz-Ortega, M., Ruperez, M. Esteban, V. Egido,

Naik, S.R., Panda, V.S. (2007). Antioxidant and J. (2003). Molecular mechanisms of angiotensin IIhepatoprotective effects of Ginkgo biloba phytosomes induced vascular injury. Curr. Hypertens Rep., 5:73in carbon tetrachloride-induced liver injury in rodents. 79.

Liver Int. 27: 393- 399.

Satapathy, S.K., Sakhuia, P. Malhorta, V. Shama,

Nakabeppu, Y., Sakumi, K. Sakamoto, K. B.C. Sarina, S.K. (2007). Benificial effects of Tsuchimoto, D. Tsuzuki, T. Nakatsu, Y. (2006). pentoxifyline on hepatic steatosis, fibrosis and Mutagenesi and carcinogenesis caused by the necroinflammation in patients with non-alcholic oxidation of nucleic acids. Biological Chemistry, 387: steatohepatitis. J Gastroenterol. Hepatol., 22(5): 634373-379. 638.

Paizis, G., Gilbert, R.E. Cooper, M.E. Murthi, P. Shan, Y., Ye, X.h. Xin, H. (2010). Effect of the Schembri, J.M. Wu, L.L. (2001). Effect of grape seed proanthocyanidin extract on the free angiotensin II type 1 receptor blockade on radical and energy metabolism indicators during the experimental hepatic fibrogenesis. J. Hepatol., 35: movement. Scientific Research and Essay, 5 (2): 148376-385.

Qin, M.Q., Zhang, G.Q. Qin, Z.L. (2006). Effects of OPC on CK,MDA,SOD,GSH-PX for Taekwondo athletes after heavy load training. J Shandong Inst. Phys. Edu. Sports, 22: 72-73.

Rajesh, M.G., Latha, M.S. (2004). Protective activity of Glycyrrhiza glabra Glycyrrhiza glabra Glycyrrhiza glabra Linn. on carbon carbon tetrachloride-induced peroxidative damage. Ind. J Pharmacol., 36 (5): 284-286.

Rana, S.V., Allen, T. Singh, R. (2002). Inevitable glutathione, then and now. Indian J Exp. Biol., 40: 706-716.

Ray, G., Husain, S.A. (2002). Oxidants, antioxidants and carcino-genesis. Indian J Exp. Biol., 40:1213-1232. 153.

Sirag, H.M., Ibrahim, H.A. Amer, A.A. Salam, T.A. Samaka, R.M. El-Mowafy, Y.A. (2011). Ameliorative effect of Caffeic Acid Phenethyl Ester and Candsartain Cilexetil on $\mathrm{CCl}_{4}$ induced Hepatotoxicity in Male Rats Annals of Biological Research, 2 (4): 503-515.

Spranger, I., Sun, B. Mateus, A.M. Freitas, V. Ricardo-da-Silva ,J.M. (2008). Chemical characterization and antioxidant activities of oligomeric and polymeric procyanidin fractions from grape seeds. Food Chem., 108: 519-532.

Stadtman, R. (2002). Oxidatively modified proteins in aging and disease. Free Radic Biol Med.,32(9): 797-803.

Surendran, S., Eswaran, M.B. Vijayakumar, M.

Ray, S.D., Kumar, M.A. Bagchi, D. (1999). A Rao, C.V. (2011). In vitro and in vivo novel proanthocyanidin IH636 grape seed extract hetpatoprrotctive activity of Cissampelos pareira increases in vivo Bcl- XL expression and prevents against carbon-tetrachloride induced hepatic damage. acetaminophen-included programmmed and Indian J Experim. Biol., 49:939-945.

unprogrammed cell death in mouse liver. Arch. Thabrew, M.I. Joice, P.D. Rajatissa, V.A. (1987). Biochem. Biophys., 369: 42- 58.

A comparative study of the efficacy of Pavetta indica

Rein, D., Paglieroni, T.G. Wun, T. Pearson, D.A. and Osbeckia octanda in the treatment of liver Schmitz, H.H. Gosselin, R. Keen, C.L. (2000). Cocoa dysfunction. Planta Med., 53: 239- 241.

inhibits platelet activation and function. Am. J Clin. Nutr., 72: 30- 35 .

Reitman, S., Frankel, S. (1957). A colorimetric method for the determination of serum glutamic oxalacetic and glutamic pyruvic transaminases. Am. J Clin. Pathol., 28:56- 63.

Tuncer, I., Ozbek, H. Ugras, S. Bayram, I. (2003). Anti-fibrogenic effects of captopril and candesartan cilexetil on the hepatic fibrosis development in rat. Exp. Toxic. Pathol., 55: 159-166.

Weinberg, A.J., Zappe, D.H. Ashton, M. Weinberg, M.S. (2004). Safety and tolerability of 
high-dose angiotensin receptor blocker therapy in patients with chronic kidney disease: a pilot study. Am. J Nephrol., 24:340-345.

Wernke, M.J., Schell, J.D. (2004): Solvent and malignancy. Clin. Occup. Environ. Med., 4: 513-527.
Yilmaz, Y., Toledo, R.T. (2004). Health aspects of functional grape seed constituents. Trends food Sci. Technol., 15: 422- 433.

Yoshij, H., Kuriyama, S. Yoshii, J. (2001). Angiotensin-II type I receptor interaction is a major regulator for liver fibrosis development in rats. Hepatology, 34: 745-750 